\title{
Kodeskift i de udvandrerdanske varieteter i Nordamerika og Argentina: Inventar, frekvens, funktion
}

\author{
JAN HEEGÅRD PETERSEN, KAROLINE KÜHL OG \\ GERT FOGET HANSEN
}

\begin{abstract}
Denne artikel analyserer den leksikalske påvirkning af dansk talt af danske indvandrere og deres efterkommere i Argentina, USA og den lille by New Denmark i den canadiske provins New Brunswick i form af brug af engelske henholdsvis spanske ord og ordstammer i ellers dansk tale. Data stammer fra Corpus of American Danish (CoAmDa), og undersøgelsen er baseret på et inventar på i alt 880.668 tokens (dvs. ord og transskriptioner af talesprogsfænomener som fx tøven). Undersøgelsen viser kvantitative forskelle mellem de tre datasæt: Data fra USA indeholder flest ikke-danske ord, data fra Argentina færrest, mens de canadiske data falder indimellem. Også i forhold til ordklasser er de tre datasæt forskellige: Talerne fra Argentina bruger fortrinsvis substantiver og diskursord fra spansk, hvorimod USA-talerne i langt højere grad bruger kodeskift fra alle ordklasser. Også på dette punkt falder dataene fra New Denmark midtimellem. Argentina-talerne ledsager langt oftere spanske kodeskift med metakommentarer, fx som vi siger, og de spanske kodeskift forekommer hyppigere $\mathrm{i}$ forbindelse med tøvemarkeringer end i de to andre datasæt. Artiklen konkluderer at disse forskelle i hvordan dansk er leksikalsk påvirket af det dominerende sprog i de tre sprogsamfund, kan relateres dels til interviewmetodiske forhold og dels til graden af typologisk slægtskab, men mere sandsynligt til de forskellige makrosociale forhold som dansk har eksisteret under.
\end{abstract}

NØGLEORD: kodeskift; CoAmDa; sprogkontakt; arvesprog; talesprogskorpus; korpuslingvistik

\section{INDLEDNING}

I denne artikel undersøger vi den leksikalske påvirkning i form af kodeskift $i$ tre forskellige former for udvandrerdansk, nemlig dansk i Argen- 
tina, dansk i USA og dansk som det blev talt i den lille by New Denmark i den canadiske provins New Brunswick. Med 'udvandrerdansk' mener vi det dansk som taltes og tales af de danske udvandrere og deres efterkommere i de nævnte udvandrerlande i tiden mellem 1966, hvor den tidligste optagelse vi har til rådighed, blev gennemført, og 2015 hvor vores sidste feltarbejde i Argentina fandt sted. Med leksikalsk påvirkning i form af kodeskift mener vi her brug af ord eller ordstammer fra majoritetssproget: spansk i Argentina, engelsk i USA og Canada.

De tre lande - USA, Canada og Argentina - har det til fælles at de har været de primære udvandringslande for danskere mellem 1850 og 1960. Sociokulturelt adskiller både landenes holdning til de danske immigranter og de danske udvandreres adfærd og holdninger til immigrationen sig imidlertid markant fra hinanden med konsekvenser for om dansk sprog blev bibeholdt og, hvis det gjorde, i hvilken form. Hvor 'det danske' i engelsksprogede omgivelser i USA hurtigt smuldrede hen (Kjær og Baumann Larsen 1974; Grøngaard Jeppesen 2005), er det i spansksprogede omgivelser i Argentina blevet videreført op til vore dage (Heegård og Kühl 2017; Hartling 2019). I New Denmark har dansk været talt i et lille og tæt netværk - i engelsksprogede omgivelser - i omkring 100 år og er blevet opretholdt i hvert fald indtil omkring 2000 (Kühl 2019).

At nordamerikadansk og argentinadansk er leksikalsk påvirket af henholdsvis nordamerikansk engelsk og af argentinsk spansk, er der i sig selv ikke noget bemærkelsesværdigt ved, særlig når der som i disse tilfælde er tale om et mindretalssprog, dansk, i samfund hvor henholdsvis engelsk og spansk er de altdominerende sprog. Det interessante som vi vil kortlægge i detaljer, er at den leksikalske påvirkning i form af kodeskift er forskellig i både art og omfang, og at vi bedømt ud fra dette leksikalske perspektiv faktisk må tale om forskellige former for udvandrerdansk. Denne konklusion når vi på baggrund af følgende forskningsspørgsmål:

- $\quad$ Er der leksikalsk kodeskift i samme omfang og grad i de tre samfund?

- Hvordan fordeler kodeskiftene i tre danske varieteter sig i forhold til ordklasser?

- Hvilken sproglig kontekst i form af forudgående pauser eller metakommentarer viser kodeskiftene i de tre varieteter? 
Artiklen har følgende struktur: Vi beskriver først kort de tre sprogsamfund $\mathrm{i}$ afsnit 2. I afsnit 3 beskriver vi Corpus of American Danish som udgør vores datagrundlag, nogle forhold $i$ korpussets opbygning som kan have haft indflydelse på resultaterne, samt principperne for transskription og annotation. Afsnit 4 indeholder en teoretisk redegørelse for leksikalsk påvirkning i sprogkontaktsituationer samt en diskussion af mulighederne for at afgøre om et ord eller en ordstamme fra majoritetssproget er blevet en etableret bestanddel af de udvandrerdanske varieteter. Afsnit 5 indeholder vores analyser, som opsummeres og diskuteres nærmere i afsnit 6 . Artiklen rundes af med en konklusion i afsnit 7.

\section{DE DANSKE SPROGSAMFUND I USA, NEW DENMARK OG ARGENTINA}

2.1 USA

Den danske udvandring til USA er beskrevet grundigt i flere udgivelser, fx Hvidt (1971) og Grøngaard Jeppesen (2005, 2010). Til trods for at emigrationen til USA har været betragtelig set med danske øjne, var den danske gruppe en mindre gruppe set med amerikanske øjne og sammenlignet med de andre nordeuropæiske udvandrergrupper. De danske indvandrere og især deres efterkommere viste overordnet set kun en svag tendens til at samles i og omkring danske bosættelseskolonier, dansk kirke og anden dansk(sproglig) kultur. Undtagelser er fx Racine County i Wisconsin, visse kvarterer i Chicago og ikke mindst bosættelserne grundlagt inden for den dansk-amerikanske 'kolonisag', hvor dansk sprog og kultur blev opretholdt (Heegård Petersen m.fl., indsendt). ${ }^{1}$ Størstedelen af dansk-amerikanerne tilpassede sig hurtigt $\mathrm{i}$ den amerikanske 'smeltedigel', og de var socialt og geografisk mobile (Grøngaard Jeppesen 2005). Den sproglige konsekvens har været at dansk overordnet set tidligt ophørte med at blive brugt som dagligsprog. Mens der i 1900 kun var 5,3\% af de danskfødte i USA der i de amerikanske censusbesvarelser (dvs. folketællinger hvor der spørges ind til en række personlige og demografiske forhold) angav at de ikke kunne tale engelsk, var dette tal i 1920 allerede faldet til 2,8\%. Dette er

1 'Kolonisagen' betegner det grundtvigiansk prægede initiativ 'Dansk Folkesamfund', som blev grundlagt i 1883-1884, og som arbejdede for oprettelsen af danske bosættelser med danske børne- og højskoler, dansk kirke, dansk sprog og dansk levevis i USA. 
lave værdier og et markant fald sammenlignet med andre immigrantgrupper (Grøngaard Jeppesen 2005: 283; Kühl 2015: 39-41). Dette billede understøttes af Kjær og Baumann Larsen (1974: 25) som konkluderer at de første danske indvandrere i midten af 1970'erne ikke længere brugte dansk som et aktivt dagligsprog. I dag er der formentlig meget få om nogen efterkommere af udvandrerne fra udvandringen før 2. Verdenskrig der stadig taler dansk.

\subsection{New Denmark, Canada}

Den lille by New Denmark i den nordvestlige del af New Brunswick blev grundlagt af danske immigranter allerede i 1872. Omkring 1920 kom der en ny, større bølge af danske indvandrere til (Lang 2005). Den landlige by har været præget af stærke netværk blandt dansk-canadierne med en dansk protestantisk kirke, en (kortlivet) dansk-canadisk højskole og dansk sommerskole i nogle år samt vedligeholdelse af danske traditioner og en i øvrigt stærk bevidsthed om den fælles oprindelse. New Denmark har således haft de historiske, sociodemografiske og sprogbrugsmæssige forudsætninger der skal til hvis der skal opstå sproglige normer: Tætte netværk i et selvbevidst immigrantsamfund som har lagt vægt på at opretholde dansk sprog. Dansk har som nævnt været opretholdt til i hvert fald 2000, og det er i skrivende stund uklart om der stadig er dansktalende tilbage i New Denmark. (Se Kühl 2018 og Kühl 2019 for beskrivelser af det danske sprog i New Denmark).

\subsection{Argentina}

Den danske udvandring til Argentina begyndte sidst i 1840'erne, ansporet af pioneren Juan (Hans) Fugl, og fortsatte til ca. 1930. Danskerne bosatte sig fortrinsvis på pampaen i den såkaldte Danskertrekant mellem Tres Arroyos inde i landet og havnebyerne Necochea og Bahía Blanca, i hovedstaden Buenos Aires og i byen Eldorado i den nordøstlige provins Misiones. I Danskertrekanten og i Buenos Aires dannede danskerne stærke netværk centreret omkring danske kirker og den danske foreningstradition. Højskoleophold, enten på en etableret højskole i Argentina eller typisk firemåneders ophold i Danmark, og for manges vedkommende en skolegang på dansk 
kostskole i Cascallares uden for Tres Arroyos, har haft en stor betydning for dansk-argentinernes videreførelse af dansk kultur og sprog. ${ }^{2}$

I Eldorado, som dansk-argentinere fra Danskertrekanten var med til at grundlægge i 1920'erne, har dansk-argentinerne ikke været talstærke, netværkene har ikke været lige så forankrende som i hovedstaden og på pampaen, og der har hverken været dansk kirke eller en vedvarende foreningstradition. Man har fejret danske højtider og holdt fester $\mathrm{i}$ forsamlingshuset, men Misiones er et flerkulturelt og flersproget område, og dansk-argentinerne har tidligt integreret sig i det omgivende samfund.

Antallet af dansk-argentinere for hvem dansk stadig i dag er et sprog der kan aktiveres, er ukendt. Selvom det danske sprog har stået stærkt i de dansk-argentinske samfund, især i Danskertrekanten, og selvom mange i den ældre generation er vokset op med dansk som førstesprog og først har lært spansk i skolen, er der formentlig kun yderst få der stadig bruger dansk i hverdagen. Det danske sprog kan dog aktiveres forholdsvis uproblematisk i samtaler, men kun for den ældste generation, dvs. personer på 70 år eller ældre. Den yngre generation mellem 40 og 60 år kan være opvokset med dansk som familiesprog, men for dem er spansk hurtigt blevet det dominerende sprog. Det dansk den gruppe behersker i dag, er typisk et inaktivt og til dels kun rudimentært husket sprog, eller et dansk som de har lært sig eller reaktiveret gennem arbejde, studier og højskoleophold i Danmark. For så vidt er dansk i Argentina et døende sprog. Spansk er for de allerfleste det dominerende hverdagssprog. ${ }^{3}$

2 Den danske udvandringshistorie til Argentina er langt fra så kendt i den danske offentlighed som udvandringen til Nordamerika, og den er fra historisk perspektiv kun sparsomt beskrevet, med den argentinske historiker María Bjerg (bl.a. 1996) som en spansksproget undtagelse, se dog Bækhøj (1948). Der findes dog erindringer og personportrætter (fx Johansen 1934 og Engwald 1938) og antropologiske og historiske specialer (fx Agertoft 2005, Jarnum 2006 og Worgall 2011).

3 For mere udførlige beskrivelser af det danske sprogsamfund i Argentina henviser vi til Heegård og Kühl (2017), Heegård og Albris (2018), Kühl og Heegård (2018), Heegård, Kühl og Hartling (2018) og Hartling (2019: 9-34). En fagfællebedømmer påpeger at talerne i nyere tid har haft mulighed for at lytte til dansk radio og se dansk fjernsyn via internettet. Dette synes dog ikke at være tilfældet i Argentina - kun én informant nævner at hun nogle gange ser danske film (og har svært ved at forstå dem). Heller ikke i Canada-optagelserne fra omkring år 2000 nævnes dansk radio som muligt sprogligt input. 


\section{CORPUS OF AMERICAN DANISH}

Datamaterialet til denne undersøgelse kommer fra Corpus of American Danish, CoAmDa (Kühl m.fl. 2017, Kühl m.fl. 2019), som udgøres af lydoptagelser og transskriptioner af interviews med danske udvandrere og deres efterkommere i USA, Canada og Argentina. Per november 2019 rummer CoAmDa samlet set 1.687 .078 tokens, ${ }^{4}$ fordelt på 337 talere fra de tre lande, $i$ alt 186 timers optagelser (Kühl m.fl. 2019).

Som beskrevet i den kortfattede udvandringshistorik repræsenterer talerne fra de tre lande ikke blot kontakt mellem forskellige sprog som er beslægtet med dansk på forskellig vis, men også forskellige bosættelsesmønstre og netværk. Datasættet giver os således mulighed for at undersøge i hvilket omfang både forskellige samfunds- og netværksforhold og omgivende sprog kan have en indflydelse på hvilke ord og morfemer der overtages fra majoritetssproget, samt af omfanget af kodeskift i de tre udvandrerdanske varieteter.

Dog er datamaterialet som indgår i CoAmDa, blevet indsamlet på forskellige tidspunkter og af forskellige indsamlere, hvilket har haft konsekvenser for sammensætningen af materialet. Langt størstedelen af USA-interviewene og en del af Canada-interviewene er optaget af Iver Kjær og Mogens Baumann Larsen i perioden 1966-1980. En mindre del af USA-interviewene er optaget af Tore Kristiansen i 1991, mens størstedelen af Canada-interviewene er optaget af den canadiske sprogforsker Christopher Hale i 1998. Argentina-interviewene er optaget i 2014-2015 i forbindelse med forskningsprojektet Danske stemmer $i$ USA og Argentina. ${ }^{5}$ Forskellen i tid gør at interviewerne har haft adgang til forskellige tekniske muligheder hvad angår fx længden af interview (de tidlige optagelser var med spolebånd og deraf afledt begrænset længde, moderne digitale optagere har ikke samme længdebegrænsning). Interviewernes sprogkompetencer har også varieret: Mens alle interviewerne i Nordamerika har kunnet tale engelsk, har de intervie-

4 'Tokens' betegner ord, men også ortografiske transskriptioner af talesprogsfænomener som fx tøven, selvafbrydelse og indslag af kortvarig latter.

5 Vi takker Inger Kjær, enke efter Iver Kjær, Tore Kristiansen og Christopher Hale for overdragelsen af de optagelser der har indgået i korpusset. Optagelserne har været i form af spolebånd, kassettebånd og digitaliserede båndoptagelser. Alle er som led i forskningsprojektet Danske stemmer $i$ US A og Argentina blevet digitaliseret og bearbejdet af Gert Foget Hansen med henblik på at blive arkiveret med den bedst mulige lydkvalitet. 
were der har deltaget i dataindsamlingen i Argentina, haft meget varierende kendskab til spansk. Sidstnævnte forhold har sandsynligvis haft konsekvenser for om informanterne har vidst at de kunne skifte til majoritetssproget uden at dette ville hindre kommunikationen.

En anden interviewmetodisk faktor der gør sig gældende i et korpus der er så sammensat som CoAmDa, er forskellene i interviewernes spørgestrategier og forskningsspørgsmål. I alle interviewsæt har interviewerne tydeligvis haft et mere eller mindre fast sæt af spørgsmål. Det er forskelligt $\mathrm{i}$ hvilken grad informanterne har fået mulighed for at tale frit om emner der spontant er opstået. Interviewene optaget af Kjær og Baumann Larsen og af Hale er som regel korte (det længste varer ca. 1 time), og interviewerne følger i det store hele en fast spørgsmålsrække. Interviewstrategien i Argentina har været anderledes. Selvom der var indlagt faste spørgsmål om fx opvækst og sprogbrug, var det også formålet at få talerne til at fortælle frit om hvad de måtte have på hjerte. Dette er lykkedes og har ført til at gennemsnitslængden for disse interview er på 90 minutter. Interviewerne har ved deres spørgsmål naturligvis også præget de semantiske felter der dukker op i løbet af interviewene. For Argentinas vedkommende spurgte interviewerne $\mathrm{fx}$ ofte til samfunds- og uddannelsesforhold for også at se om talernes danskkundskaber også rakte til at beskrive sådanne lokalt forankrede forhold, ${ }^{6}$ mens Christopher Hale i sine interview i den canadiske by New Denmark har spurgt ind til talernes hovedbeskæftigelse inden for kartoffeldyrkningen. Herigennem har interviewene genereret mange engelske fag- eller kulturord som tilhører det semantiske felt 'kartoffeldyrkning' (dette har givet anledning til artiklen om 'kartoffelavlerdansk', Kühl 2019). Et eksempel på semantiske felter som produkt af emnefokuseringen $\mathrm{i}$ interviewene ses $\mathrm{i}$ de mange forekomster af verberne 'født', 'konfirmeret' og 'gift' og deres semantiske forandring (Heegård Petersen og Kühl 2017).

At CoAmDa er sammensat af forskellige datasæt, har altså helt generelt leksikalske konsekvenser og dermed også konsekvenser for leksikalske kodeskift. Ikke desto mindre følger alle interviewerne en sammenlignelig interviewstrategi med sammenlignelige mål, nemlig at dokumentere udvandrernes dansk og kortlægge brugen af dansk i for-

6 For en nærmere beskrivelse af interviewstrategier henviser vi til Kühl m.fl. (2017). 
skellige sammenhæng. På trods af forskellene mener vi derfor at det både er muligt og giver mening at bruge CoAmDa som basis for en undersøgelse af leksikalske kodeskift i de udvandrerdanske varieteter.

\subsection{Principper for transskription og annotation}

Transskriptionsprincipperne for CoAmDa følger det såkaldte LANCHART-korpus under Sprogforandringscentret ved Københavns Universitet (Gregersen m.fl. 2015). Dette vil sige at alle ikke-danske ord er markeret som henholdsvis spanske, engelske mv. I en efterfølgende semiautomatisk behandling er alle tokens tillige blevet tildelt en annotationskategori, fx: "dansk", "hybrid" (dvs. ord med ordinternt kodeskift som fx campleje 'forpagtning af landbrugsjord'; fremover betegnet 'blandingsord'), "selvafbrydelse" (alle tokens markeret med bindestreg, fx afbryd-), "tøveord" og "proprium". 7 Ud over den ordbaserede annotation indeholder korpusset også en syntaktisk baseret annotation der markerer alle helsætninger som enten engelske, spanske eller danske, hvor 'sætning' er defineret kategorisk som en syntaktisk konstruktion med subjekt, evt. elliptisk, og finit verbum. De nedenstående analyser er baseret på denne syntaktiske annotation idet vores data er udtrukket fra alle de helsætninger der er kategoriseret som danske.

Data er udtrukket vha. et script tilpasset Praats TextGrid-format. ${ }^{8}$ Scriptet har udtrukket alle ord i danske sætninger, som defineret ovenfor, der har tokenannotationerne 'dansk', 'spansk', 'engelsk' og 'hybrid' (dvs. blandingsord). Idet tokeninddelingen i Praat er baseret på ortografisk selvstændige ord, vil leksikaliserede flerordsforbindelser som fx of course 'selvfølgelig' og tren de carga 'godstog' fremtræde som henholdsvis to og tre ord. Det vil give et misvisende billede af hvor mange og ikke mindst hvilke ord fra majoritetssprogene der bruges, hvis en

7 Proprier udgør en særlig leksikalsk enhed hvad angår sprogblanding idet de i deres udtale i højere grad synes at indeholde elementer fra både dansk og engelsk eller spansk hvorfor en entydig sprogannotation ikke har været mulig, ligesom det heller ikke har været muligt at anvende en særlig kategori for andre ord med fonologisk tvetydighed. Vi holder derfor proprier ude fra denne undersøgelse i en særlig tokenkategori. Se i øvrigt Kühl m.fl. (2018) og Kühl m.fl. (2019) for detaljerede beskrivelser af annotationsprincipperne i CoAmDa og en nærmere beskrivelse af øvrige tokenannotationer.

8 Scriptet er udviklet af Gert Foget Hansen. Dokumentation kan erhverves ved henvendelse. Se Boersma og Weenink (2019) for en beskrivelse af lydbehandlingsværktøjet Praat. 
beregning ikke tog højde for dette. Vi har derfor på basis af udtrækkene analyseret den nære kontekst for hvert ord eller morfem fra majoritetssproget og truffet en afgørelse om hvorvidt det indgik i et etableret flerordslemma. Principperne for denne procedure var støttet af ordbogsopslag. Eksempler på sådanne flerordsforbindelser fra engelsk er 'diskursord' (se definition nedenfor) som of course, all right, I know, I guess, you know, partikelverber som get out, fade out, make up, særskrevne sammensætninger som ice cream, first cousin, floral designer, kerosene lamp, school bus, determinativer som quite a, a lot of, lots of og talord, som fx two thousand $\mathrm{m}$.fl. Flerordsforbindelser fra spansk er fx sammensætninger som técnico agrario 'landbrugstekniker', sociedad anónima 'aktieselskab', tinta cbina 'tusch', tiro al blanco 'målskydning', usufructu vitalicio 'livslang brugsret', tren de carga 'godstog', diskursord som a ver 'lad mig se', o sea 'med andre ord', qué se yo 'hvad ved jeg', y bueno 'nå men' og talord som fx sesenta y ocho '68'.

\subsection{Datagrundlag for den foreliggende undersogelse af leksikalsk kodeskift}

Data til denne undersøgelse er udtrukket i maj 2018. De interview der indgår, har en samlet længde på 163 timer, og hele datasættet rummer i alt 886.535 tokens fordelt på 299 talere. Tabel 1 viser fordeling af tokens, talere og antal transskriberede timer på korpusset opdelt efter geografisk sted.

TABEL 1. DE TRE DATASÆT UDTRUKKET FRA CORPUS OF AMERICAN DANISH (COAMDA) FOR NÆRVÆRENDE UNDERSØGELSE

\begin{tabular}{llll}
\hline & USA & New Denmark & Argentina \\
\hline Talere & 176 & 43 & 78 \\
\hline \multirow{2}{*}{ Optagelsesår } & $\begin{array}{l}1966,1967,1973, \\
1976,1980,1982, \\
\end{array}$ & 1998 & 2014,2015 \\
\hline Timer & 4690,1991 & & \\
\hline Tokens & 271.663 & 14 & 103 \\
\hline
\end{tabular}


TABEL 2. TALERSAMMENSÆTNINGENS SOCIALE FAKTORER FOR NÆRVÆRENDE UNDERSØGELSE

\begin{tabular}{llll}
\hline & USA & New Denmark & Argentina \\
\hline Fødeår & $1870-1939$ & $1891-1941$ & $1911-1971$ \\
\hline \multirow{2}{*}{ Aldersspænd } & $40-97$ (median 87) & 43-91 (median 68) & $\begin{array}{l}\text { 44-103 (median } \\
75)\end{array}$ \\
& & Nordamerika 29 & Argentina 73 \\
\multirow{3}{*}{ Fødested } & Nordamerika 54 & Danmark 3 & Andet 2 \\
& Danmark 119 & Andet 1 & 27 mænd \\
& Andet 3 & 27 mænd & 51 kvinder \\
\hline \multirow{2}{*}{ Køn } & 81 mænd & 16 kvinder & \\
\hline
\end{tabular}

Særligt to forhold ved talersammensætningen og datasættene springer i øjnene. For det første er hele $66 \%$ af talerne fra USA født i Danmark (og de er stort set alle udvandret som unge voksne, Kühl m.fl. 2019). De har altså talt flydende dansk ved udvandringstidspunktet. Heroverfor er de fleste informanter i New Denmark og Argentina født i udvandringslandet, men af de 13 Danmark-fødte i New Denmark er kun 3 udvandret før sproget er blevet tilegnet (3 Danmark-fødte talere mellem 0-3 år, 10 Danmark-fødte talere ældre end 12 år ved udvandring). Kun 3 af talerne fra Argentina er født i Danmark, og de er udvandret sammen med deres forældre som små børn. Alle talerne i korpusset som ikke er født i Danmark, er enten vokset op tosproget eller med dansk som førstesprog i hjemmet og majoritetssproget som et senere tillært andetsprog, senest i skolen. Talerne i Argentina er blevet fundet ved at spørge informanter om de kendte andre der kunne tale dansk og måske ville være villige til at tale med os. Vi ved ikke meget om hvordan Kjær og Baumann Larsen og Hale fandt frem til deres talere (men se Kühl m.fl. 2017 for en redegørelse).

For det andet er der færre interviewede fra Argentina end fra USA, men antallet af transskriberede timer og hermed ord er betragteligt højere. Dette er et udslag af interviewforholdene og -strategierne som nævint ovenfor.

\section{KODESKIFT OG LEKSIKALSK PÅVIRKNING}

\subsection{Leksikalsk kodeskift}

At bruge leksikalske elementer fra flere sprog eller sprogvarieteter in- 
den for en ytring er på ingen måde usædvanligt. Leksikalsk kodeskift ${ }^{9}$ kan iagttages i de fleste af verdens sprog, men som regel stiger antallet af ord fra et andet sprog afhængigt af intensiteten af kontakten mellem sprogene, dvs. om talerne bruger sprogene side om side i deres hverdag, om de fortrinsvist taler det ene sprog og kun ved sjældne lejligheder det andet, om ytringerne produceres inden for en gruppe af tosprogede personer med de samme sprog(varieteter) $i$ en lignende kompetencegrad, eller om graden af sprogkompetence i talergruppen er forskellig. I situationer af intens sprogkontakt eller internt i en tosproget gruppe med samme kombination af sprog er brugen af ord eller morfemer fra de relevante $\operatorname{sprog}$ (varieteter) ikke begrænset i forhold til forståelse fordi alle taler de involverede sprog. Dette giver i princippet mulighed for uhindret blanding af sprogene leksikalsk set. I denne 'tosprogede tilstand' (Grosjean 2001), hvor der er minimal risiko for kommunikativt sammenbrud ('communicative failure'), kan kodeskift være pragmatisk umarkeret og udgøre en upåfaldende måde at tale på. Dette ses i alle optagelser der indgår i CoAmDa, hvor ytringer som de følgende er normen snarere end undtagelser:

(1) Sprogskift for et enkelt ord: 'Vi havde en store i byen'.

(2) Sprogskift i en fast flerordsforbindelse: 'Han kom i fem-ogsixty'.

(3) Sprogskift mellem stamme og bøjningsendelse: 'De shippede dem til Montreal'.

(4) Sprogskift mellem stammer i sammensatte ord: 'Vi bruger en kartoffelharvester?

I denne artikel skelner vi begrebsmæssigt mellem to slags kodeskift: Kodeskift som tager form af blandingsord, dvs. ord der enten er sammen-

9 I den engelsksproget litteratur, som er dominerende inden for kontaktlingvistikken, bruges både 'code-switching', 'code-mixing' og 'borrowing'. Til trods for at der har været nogle forsøg på at udrede begreberne, er der stadig en del variation (Gardner-Chloros 2009: 10-13). Som reaktion på 'borrowing' har Matras (2009: 146) introduceret begrebet 'replication' og Johanson (2008) begrebet 'copying'; begge dele er forsøg på at gøre det klart at a) kodeskift kan integreres i det modtagende sprog $\mathrm{i}$ en grad så det ikke længere står klart at det oprindeligt er blevet overtaget fra et andet sprog, og at b) borrowing-begrebet fokuserer på ejerskabsforhold snarere end på den dynamiske proces det er når talere udvælger og optager et sprogligt element, integrerer og bruger det. 
sat af to stammer fra dansk og det respektive majoritetssprog eller sammensat af en stamme fra det ene sprog og fleksion eller derivation fra det andet sprog (jf. eksemplerne (3) og (4)), og kodeskift som består af ikke-sammensatte ord fra majoritetssproget (jf. eksemplerne (1) og (2)).

Sprogvidenskabeligt er kodeskift blevet undersøgt fra forskellige vinkler og med forskellige mål, fx undersøger psykolingvistikken aktivering og kontrol af sprogene. Andre undersøgelser har sigtet mod at kortlægge kodeskiftenes funktion i et mikro- eller makrosocialt perspektiv. Det makrosociale perspektiv relaterer brugen af sprog til de sociale, økonomiske og politiske omstændigheder som udgør den flersprogede talergruppes virkelighed, mens det mikrosociale perspektiv søger at kortlægge kodeskiftenes funktion $\mathrm{i}$ interaktion, $\mathrm{fx}$ til at markere insiderviden eller -status ved at bruge begreber fra specifikke domæner. En mere sproglig tilgang har været at undersøge empirisk hvor i ytringen kodeskiftene optræder, og hvilken form de antager. Flere modeller, fx Poplacks 'Constraint-based model (Poplack 1980) og Myers-Scottons 'Matrix Language Frame ModeP (Myers-Scotton 1993, 2002), har opstillet rammer for hvornår specifikke former for kodeskift vil optræde, uafhængigt af de deltagende sprogs grammatiske karakteristik og uafhængigt af de sociale omstændigheder i hvilke kodeskiftene produceres. Modellernes forudsigelser har vist sig at beskrive tendenser snarere end absolutte restriktioner (Muysken 2000: 60-95). Nyere undersøgelser af kodeskift (eller sprogkontaktfænomener generelt) har med succes kombineret flere tilgange og beskriver kodeskift som afhængigt af sociale og til dels psykolingvistiske faktorer, fx Thomason (2001), Matras (2009) og Muysken (2013).

Denne artikel kombinerer en lingvistisk analyse med et makrosocialt perspektiv: Vi kortlægger forekomsten af spanske og engelske ord og ordstammer i de danske udvandreres danske ytringer. Vi analyserer forekomsten af kodeskift kvantitativt, og vi ser nærmere på hvilke ordklasser der optræder, om ordene fra majoritetssprogene betegner kulturspecifikke forhold fra indvandringslandet, og om sprogproduktionskonteksten kan sige noget om hvorfor der kodeskiftes. Resultaterne fra denne analyse relaterer vi til graden af genetisk og typologisk beslægtethed mellem de involverede sprog og til vores viden om den sociale, økonomiske og politiske status blandt de danske udvandrere i 
Nordamerika og Argentina. Vores kortlægning og sammenligning af den leksikalske påvirkning af udvandrerdansk i Argentina, Nordamerika og den canadiske by New Denmark beror altså også på en kombination af forskellige tilgange.

\subsection{Ordklassefordeling ved kodeskift}

Som udgangspunkt for vores analyser af fordeling af ordklasser i kodeskiftene i amerikadansk og argentinadansk er det oplagt at se på de tendenser og forslag til hierarkier på tværs af mange sprog der er blevet opstillet $\mathrm{i}$ litteraturen. Hierarkierne har to forskellige udgangspunkter: Det ene er frekvens, dvs. graden af sandsynlighed for om en grammatisk kategori fra det andet sprog bruges, det andet er om brug af en specifik kategori fra et andet sprog har implikationer for brugen af også andre kategorier. Matras opstiller følgende frekvensbaserede hierarki af ordklasser baseret på undersøgelser der inddrager 27 forskellige sprog:

"nouns, conjunctions $>$ verbs $>$ discourse markers $>$ adjectives $>$ interjections $>$ adverbs $>$ other particles, adpositions $>$ numerals $>$ pronouns $>$ derivational affixes $>$ inflectional affixes". (Matras 2007: 61)

Dette er langtfra det eneste hierarki i litteraturen (se Matras 2009: 153-165 for et overblik og en diskussion). Der er forskelle mht. hvor i hierarkiet de enkelte ordklasser placeres, men et generelt træk som alle hierarkier er fælles om, er at indholdsord eller -morfemer ligger øverst på skalaen, mens funktionsord eller -morfemer mere sjældent optræder som kodeskift, med undtagelse af diskursstrukturende ord som interjektioner, diskursmarkører og konjunktioner, som tidligt og tit overtages fra kontaktsproget. Hierarkierne afspejler således til dels ordklassernes indbyrdes forhold i leksikon hvor de åbne ordklasser (indholdsordene, især substantiver og verber) udgør en langt større del end de lukkede klasser (funktionsordene og -morfemerne). Forskellen mellem de åbne og lukkede ordklasser vil altså have en effekt på både antallet af forekomster (tokens) og antallet af leksikalske typer (types) (se Matras 2007: 32 for en diskussion af frekvenseffekter). Denne effekt 
af forskelligt antal af ord i de lukkede og de åbne klasser er blevet imødegået i Matras' hierarki idet han som udgangspunkt ikke har brugt frekvens som basis, men blot forekomsten af en ordklasse i de datasæt fra de 27 sprog som hierarkiet er baseret på. Med andre ord: Jo flere sprog der overtager den pågældende ordklasse fra et andet sprog, jo højere på det ovennævnte hierarki placeres ordklassen.

Som nævnt ovenfor er et andet forhold der går igen $i$ andre hierarkier og undersøgelser, at diskursmarkører og konjunktioner ligger meget højt på skalaen over hvilke ord der overtages fra andre sprog (Matras 1998; Salmons 1990; Boas og Weilbacher 2007; Lipski 2005). Diskursmarkører, som $\mathrm{fx}$ dansk foranstillet ser $d u$, altså, nå eller efterstillet såmand, ik.k' m.fl., har en del til fælles med sætningsforbindende sideordningskonjunktioner som og, men og eller. Både diskursmarkør og de sætningsforbindende konjunktioner er tekststrukturerende, ytringsforbindende elementer og derfor funktionelt beslægtede i deres rolle som konnektorer. Fælles for begge kategorier er også at de optræder i sætningsperiferien. Ifølge Stolz og Stolz (1996: 111) er disse fælles træk årsag til at konjunktioner og diskursmarkør af talerne opfattes som meget lig hinanden, og at konjunktioner fra kontaktsproget derfor hyppigt indlånes i sprogkontaktsituationer, til trods for at de er funktionsord. Der kommer med andre ord en informationsstrukturel dimension ind over den grammatiske, ordklassebaserede. Vi behandler i denne artikel derfor diskursmarkører, interjektioner og sideordningskonjunktioner som en fælles, pragmatisk-funktionelt defineret gruppe som vi betegner som 'diskursord'. Ellers opererer vi med de traditionelle ordklasser, substantiv, verbum, adjektiv, adverbium, talord, pronomen og udråbsord. Vi afprøver de tendenser der er opstillet i kodeskiftshierarkierne, på ord fra majoritetssproget og på blandingsord. ${ }^{10}$

\subsection{Kulturspecifike ke kodeskift}

Set ud fra en semantisk vinkel er der forskel på hvilke elementer der overtages fra kontaktsproget, og hvad baggrunden er: I enhver sprog-

10 Det er en opgave for kommende studier at undersøge om det fortrinsvist er inden for visse bøjningskategorier (bestemthed, numerus, diatese, tempus ...) at stammer fra majoritetssproget integreres med dansk, ligesom det heller ikke er undersøgt om adjektiver fra kontaktsprogene som er danskflekterede, fortrinsvis bruges i attributiv eller prædikativ funktion. 
kontaktsituation vil der være kulturspecifikke koncepter der ikke uden videre kan oversættes, eller hvor en oversættelse ville kræve en lang forklaring. Et aktuelt eksempel er det danske 'hygge', der er genstand for adskillige engelsksprogede publikationer (hvor det ikke oversættes). De kulturspecifikke begreber findes selvfølgelig også i nordamerikansk og argentinsk dansk. De betegner forhold, sociale aktiviteter, begivenheder, naturfænomener (fx flora og fauna), genstande og/eller organisatoriske eller institutionelle fænomener der enten kun eksisterer i henholdsvis USA, Canada og Argentina, eller som i kraft af indvandringshistorien eller talernes livserfaring og arbejdsliv må siges at være særligt prægnante for livet som (efterkommer af en) indvandrer. Eksempler er fx det var slemme tider under The Depression og jeg hoboede ('vagabonderede ved at hoppe på et tilfældigt godstog der kørte fra sted til sted'), og når Argentina-talerne taler om peludo og molita (forskellige slags bæltedyr) og om en camioneta'en lille lastbil, nærmest af en pickuptype'. Kodeskift af denne lokalt forankrede type har modtagersproget umiddelbart ikke ord for, og derfor bliver de kulturspecifikke kodeskift en selvfølgelig del af de udvandrerdanske varieteter.

\subsection{Leksikalsk paivirkning ved kodeskift}

For at kunne redegøre for om og hvordan et majoritetssprog leksikalsk har påvirket udvandrerdansk, er der i hvert fald tre aspekter der skulle tages hensyn til:

1) Vi har været nødt til på forhånd at bestemme hvad der er danske ytringer som engelske og spanske kodeskift Tempus kan forekomme i.

2) Vi har været nødt til at sandsynliggøre at et givet ord ikke er eller har været er del af det etablerede danske ordforråd.

3) Vi har været nødt til at forholde os til forskellen mellem kodeskift der fungerer som ad hoc-løsninger på et kommunikativt behov, og et kodeskift som kan betragtes som etablerede elementer af de udvandrerdanske varieteter.

Definitionen af hvad der er danske ytringer (punkt 1), har vi redegjort for i 3.1 (dansk subjekt og finit verbum). At et givet ord er dansk, har 
vi afgjort ved opslag i Ordbog over det danske sprog (ODS): Findes ordet i dette opslagsværk belagt fra før udvandringstidspunktet, har vi betragtet det som del af det (standard)danske ordforråd ved udvandringstidspunktet ${ }^{11}$. Hermed kan det være medudvandret og er derfor ikke et udtryk for påvirkningen af dansk i det nye land. Findes det ikke belagt i ODS før udvandringstidspunktet, har vi anset det for et kodeskift i henholdsvis nordamerika- og argentinadansk. Punkt (3), hvorvidt et kodeskift er produkt af en spontan overtagelse fra majoritetssproget, eller om det er del af en etableret måde at tale henholdsvis nordamerika- eller argentinadansk på, har mange aspekter som vi kun til dels kan undersøge på baggrund af vores datamateriale. Helt overordnet kan vi slå fast at hverken argentinadansk eller nordamerikadansk kan beskrives uden at tage de leksikalske elementer fra engelsk og spansk med som de danske udvandrere med tiden har taget ind i deres danske sprog, og som er blevet en naturlig del af de udvandrerdanske varieteter. Som sådan er argentinadansk og nordamerikadansk altså $i$ sig selv leksikalsk påvirkede af majoritetssprogene. Men går vi mere i dybden mht. at bestemme hvilke specifikke andresproglige ord eller morfemer der kunne regnes som en etableret del af sprogene, støder vi på forskellige problemer der bl.a. skyldes at udvandrervarieteterne ikke er standardiserede sprog. Der findes fx kun forholdsvist lidt skrevet argentina- eller nordamerikadansk som kunne bruges til at vurdere om visse ord eller morfemer fra majoritetssprogene er så etablerede at de også bruges umarkeret på skrift i formelle teksttyper.

Med udgangspunkt i vores talesprogsdata findes der i princippet en række kriterier som vi ideelt set kan bruge til at nærme os en afgørelse af om et ord eller et morfem fra majoritetssproget er en etableret del af argentinadansk, New Denmark-dansk eller USA-dansk. I realiteten er vores muligheder for at anvende kriterierne dog mere begrænsede (se nedenfor).

$11 \mathrm{Fx}$ er ordene farm, farmer og at farme kendt i Danmark siden sidst i det 19. århundrede, og som sådan kan ordformerne gælde som danske. Men ODS kommenterer "næsten kun m.h.t. forhold i engelsktalende lande" (jf. farme 1, ODS, bindet tryk i 1922). Konceptet er altså tydeligvis importeret fra USA, og det er ikke til at vide, om CoAmDas emigranttalere har kendt ordene fra Danmark (i så fald bør ordformerne regnes som danske), eller om de har erhvervet ordet $i$ alle dets former i USA og Canada. 
a) Kvantitativt kriterie: Forekommer et kodeskift forholdsvist tit, og bruges det af forskellige talere?

b) Morfologisk kriterie: Bliver kodeskiftsordet integreret i dansk ved at blive forsynet med danske bøjningsformer eller danske orddannelser?

c) Fonologisk kriterie: Udtales kodeskiftsordet med foner eller prosodi fra majoritetssproget?

d) Leksikalsk kriterie: Bruges kun dette ord eller stamme som kodeskift, eller skiftes der mellem andre leksemer, fx bruges der kun at farme eller også at (op)dyrke?

e) Sprogproduktionskriteriet: Optræder kodeskiftsordet fx efter en tøven eller sammen med et andet kodeskiftsord som kan have udløst kodeskiftet i første omgang?

Det kvantitative kriterie skal anvendes varsomt. Mens man kan skønne at et specifikt kodeskift er en etableret del af fx argentinadansk når det forekommer tit og bruges af mange talere, holder argumentationen ikke omvendt. Forekomsten af et leksem er kontekstafhængig, og derfor kan man ikke af få eller ingen forekomster slutte sig til at kodeskiftet ikke er etableret. New Denmark-farmerne taler om deres kartoffeldyrkning og bruger forskellige engelske begreber inden for dette leksikalske felt. At de samme engelske begreber ikke forekommer i USA-dansk, kan vise at de ikke er etableret i denne varietet, men det kan også være et resultat af at kartoffeldyrkning ikke var vigtigt nok til at blive taget op $i$ interviewene. Det morfologiske kriterium kan vi anvende ved at se på om $\mathrm{fx}$ substantiver eller verber forsynes med danske bøjningsendelser. Det fonologiske kriterium kan vi p.t. ikke anvende fordi vores data er udskrevet i standardortografi og ikke er forsynet med transskription af lyd, og en aflytning af alle kodeskift er en enorm opgave som desuden er vanskelig på grund af udtale der ikke entydigt kan tilforordnes ét sprog (Kühl m.fl. 2017). Det leksikalske kriterie kræver en omfattende opmærkning af leksikalske felter og synonymer. Denne form for kortlægning af leksikalsk variation er blevet gennemført for New Denmark-datasættet i forhold til de verber der i dette lille samfund bruges om kartoffeldyrkningen (Kühl 2019), men vi har ikke en opmærkning for hele CoAmDa. Derfor kan vi i vores undersøgelse 
ikke vurdere den leksikalske variation i forhold til kodeskift, jf. punkt d) ovenfor. Vi kan dog forholde os til sprogproduktionskriteriet idet opmærkningen i CoAmDa giver os mulighed for at se på den kontekst hvor kodeskiftet forekommer. Til trods for disse begrænsninger kan en kvantitativ kortlægning og morfologisk analyse give os et velfunderet billede af leksikalske påvirkning af argentinadansk og nordamerikadansk i form af ord fra majoritetssproget og blandingsord.

\section{KVANTITATIVE ANALYSER}

Vi ser i dette afsnit nærmere på distributionen af først ordene fra majoritetssproget og dernæst blandingsordene i de tre datasæt. Tabel 3 viser den overordnede fordeling.

TABEL 3. ANDEL AF ORD FRA MAJORITETSSPROGET OG BLANDINGSORD INKL. LEKSIKALISEREDE FLERORDSFORBINDELSER I DE TRE DATASÆT

\begin{tabular}{llll}
\hline & USA & New Denmark & Argentina \\
\hline $\begin{array}{l}\text { Ord fra } \\
\text { majoritetssproget }\end{array}$ & $7.019(2,6 \%)$ & $1.647(1,8 \%)$ & $3.768(0,7 \%)$ \\
Blandingsord & $440(<0,1 \%)$ & $106(0,1 \%)$ & $333(<0,1 \%)$ \\
Danske ord & $237.789(87,5 \%)$ & $82.681(90,1 \%)$ & $469.380(90,8 \%)$ \\
Andre & $26.415(9,7 \%)$ & $7.363(8,0 \%)$ & $43.728(8,5 \%)$ \\
\hline Total & $271.663(100 \%)$ & $91.797(100 \%)$ & $517.209(100 \%)$ \\
\hline
\end{tabular}

"ANDRE" OMFATTER BL.A. TØVEORD, LATTER ORTOGRAFERET SOM HA, SELVAFBRYDELSER OG PROPRIER.

Tabellen viser først og fremmest at selvom der forekommer ord fra majoritetssproget og blandingsord i alle tre datasæt, så udgør de danske ord det overvældende flertal, dvs. at der tales dansk i interviewene. Ikke desto mindre er der forskel mellem de tre datasæt: USA-talernes andel af ord fra majoritetssproget og blandingsord er større end New Denmark-talernes, som igen er større end Argentina-talernes. Disse forskelle er statistisk signifikante. ${ }^{12}$ På trods af at der generelt bruges få ord fra majoritetssprogene $\mathrm{i}$ talernes danske, gøres det altså i signifikant forskelligt omfang.

12 Chi-i-anden-test: ord fra majoritetssproget: USA vs. New Denmark, $\mathrm{p}<0,001$; ord fra majoritetssproget: New Denmark vs. Argentina, $\mathrm{p}<0,001$; blandingsord: USA vs. New Denmark, $\mathrm{p}<0,002$; blandingsord: New Denmark vs. Argentina, $\mathrm{p}<0,001$. 


\subsection{Ord fra majoritetssproget}

Vi finder ord fra majoritetssproget i alle ordklasser, både blandt indholdsord og funktionsord, jf. tabel 4.

TABEL 4. ORD FRA MAJORITETSSPROGET FORDELT PA ORDKLASSE I ALLE TRE DATASÆT

\begin{tabular}{llll}
\hline & USA & New Denmark & Argentina \\
\hline Diskursord & $2.327(33,1 \%)$ & $459(27,9 \%)$ & $1.923(51,0 \%)$ \\
Substantiv & $1.724(24,6 \%)$ & $584(35,5 \%)$ & $1.270(33,7 \%)$ \\
Adverbium & $616(8,8 \%)$ & $139(8,4 \%)$ & $98(2,6 \%)$ \\
Adjektiv & $384(5,5 \%)$ & $137(8,3 \%)$ & $116(3,1 \%)$ \\
Verbum & $554(7,9 \%)$ & $82(5,0 \%)$ & $47(1,1 \%)$ \\
Andet & $1.414(20,1 \%)$ & $246(14,9 \%)$ & $314(8,3 \%)$ \\
\hline Total & $7.019(100 \%)$ & $1.647(100 \%)$ & $3.768(100 \%)$ \\
\hline
\end{tabular}

DISKURSORD = DISKURSMARKØRER, KONJUNKTIONER OG INTERJEKTIONER; ANDET = ARTIKEL, INFINITIVMÆRKE, NUMERALER, PRONOMEN, PRÆPOSITION.

Tabellen viser både forskelle og ligheder mellem ordklassernes andel af ord fra majoritetssproget i de tre datasæt. Vi kan opstille de respektive ordklassers andel i følgende tre hierarkier, hvor | markerer en grænse på $10 \%$.

USA: Diskursord $>$ substantiv $>$ andet $\mid>$ adverbium $>$ verbum $>$ adjektiv

New Denmark: Substantiv $>$ diskursord $>$ andet $\mid>$ adverbium $>$ adjektiv $>$ verbum

Argentina: Diskursord $>$ substantiv $>\mid$ andet $>$ adjektiv $>$ adverbium $>$ verbum

En signifikanstestning viser at forskellene mellem de tre datasæt for hver ordklasse er signifikante, med undtagelse af substantiver mellem New Denmark og Argentina på 36 \% og $34 \%$ og Andet-kategorien mellem New Denmark og USA på $15 \%$ og $20 \%$.

Sammenligner vi med hierarkierne i litteraturen (afsnit 3.2), kan vi sige at Argentina-talerne er mere konservative end USA- og New Denmark-talerne idet mere usædvanlige ordklasser i højere grad er til stede $i$ de to sidstnævnte datasæt. At adjektiver og adverbier $i$ alle tre datasæt ikke fylder meget, er ikke nogen overraskelse. Sammenholder 
vi resultaterne med kodeskiftshierarkiet, er det overraskende at verber fylder så lidt $\mathrm{i}$ alle tre datasæt. Dette vender vi tilbage til i analysen af blandingsordene.

Som nævnt i afsnit 4 kan sprogproduktionskonteksten bruges som et blandt mange kriterier for om et ord fra majoritetssproget optræder umarkeret i dansk tale. Vi har derfor set på hvad der oftest forekommer foran et ord fra majoritetssproget: tøven, et andet ord fra majoritetssproget eller dansk. I denne optælling har vi regnet et tøveord, en pause og et selvafbrudt ord som et udtryk for hvad vi overordnet kan kalde et processeringsproblem, og vi har kaldt forekomsten af disse talesprogsfænomener for 'tøven'. Tabel 5 viser andelen af ord fra majoritetssproget efter tøven sammenlignet med forekomsten efter et dansk ord, et andet ord fra majoritetssproget, et blandingsord og andre kontekster.

TABEL 5. PRÆKONTEKST FOR ORD FRA MAJORITETSSPROGET, ENGELSK (USA OG NEW DENMARK) OG SPANSK (ARGENTINA)

\begin{tabular}{llll}
\hline & USA & New Denmark & Argentina \\
\hline Dansk ord & $2.502(35,6 \%)$ & $721(43,8 \%)$ & $1.371(36,4 \%)$ \\
Ord fra majoritetssproget & $1.568(22,3 \%)$ & $270(16,4 \%)$ & $558(14,8 \%)$ \\
Tøven & $1.348(19,2 \%)$ & $368(22,3 \%)$ & $1.086(28,8 \%)$ \\
Sætningsinitialt & $1467(20,9 \%)$ & $258(15,7 \%)$ & $674(17,9 \%)$ \\
Andre & $134(2,0 \%)$ & $30(1,8 \%)$ & $74(1,9 \%)$ \\
\hline Total & $7.019(100 \%)$ & $1.647(100 \%)$ & $3.763(100 \%)$ \\
\hline
\end{tabular}

TØVEN = TØVEORD, PAUSE OG SELVAFBRYDELSE. ANDRE = BLANDINGSORD, UFORSTÅELIGT ORD, LATTER, PROPRIUM OG UDBRUD.

Tabellen og signifikansberegningerne af tallene afslører interessante forskelle for de tre datasæt. I USA-sættet er andelen af ord fra majoritetssproget foran et andet ord fra majoritetssproget signifikant højere end i New Denmark-sættet og Argentina-sættet. ${ }^{13}$ Dette peger på at ord fra majoritetssproget i højere grad forekommer i sekvenser i USA, dvs. at USA-talerne i højere grad end de andre talere bruger flere engelske ord ad gangen.

Hvad angår ord fra majoritetssprogets forekomst efter tøvesignaler, tøver Argentina-talerne signifikant mere end New Denmark-talerne,

13 Forskellen mellem USA og New Denmark er signifikant, $\mathrm{p}<0,001$. Forskellen mellem New Denmark og Argentina er ikke, p = 0,22. 
som tøver signifikant mere end USA-talerne. ${ }^{14}$ Hvis tøven regnes som udtryk for bevidsthed om sprogskift, så kan dette resultat fortolkes som at Argentina-talerne er mere bevidste om kodeskift end de nordamerikanske talere, og tilsvarende at USA-talerne ikke er særligt opmærksomme på kodeskift. New Denmark-talernes grad af opmærksomhed falder imellem de to yderpunkter.

Også hvad angår sætningsinitial position, deler data sig i to grupper: I USA-sættet er der signifikant flere forekomster af ord fra majoritetssproget sætningsinitialt end der er i de to andre datasæt, $\mathrm{p}<0,001$. Der er ikke forskel på New Denmark- og Argentina-data i denne henseen$\mathrm{de}, \mathrm{p}=0,09$. Vi tilskriver dette en tilbøjelighed til at USA-talerne indleder ytringer med well'altså, nå' og see 'ser du'. Disse engelske diskursord er så at sige upåfaldende idet de ligner danske ord der også på dansk kan bruges i diskursiv funktion foranstillet eller efterstillet, fx ser $d u$, vel. ${ }^{15}$ Det er dog påfaldende og må foreløbigt stå ubesvaret hvorfor de engelskpåvirkede New Denmark-talere tilsyneladende ikke har denne 'strategi' i lige så høj grad.

I vores data fra Argentina-talerne har vi tit bemærket at et ord fra majoritetssproget kan ledsages af en metakommentar, som $\mathrm{fx}^{16}$

(5) der er sådan nogle store oh P hvad hedder det en barrancas hedder det berovre (Argda, SBB)

(6) de aldre de sagde P tranquera P tranquera i stedet for (Argda, ICL)

(7) man drikker noget som hedder tereré og det er den kolde mate (Argda, $\mathrm{EON})$

(8) og born P de P gik til P nogle P Danish classes som vi kaldte dem (NDda, ROJ)

(9) nu kan jeg altså ikke huske hvordan man siger P nurse på dansk syge (NDda, EJN)

14 Forskellen mellem USA og New Denmark er signifikant, $\mathrm{p}=0,004$. Forskellen mellem New Denmark og Argentina ligeså, $\mathrm{p}<0,001$.

15 Foranstillet 'vel' kan stadig høres blandt mennesker født omkring 1945 eller ældre. Det er et levn fra ældre dansk, jf. ODS vel, betydning 10.2., og det må derfor gælde som en etableret del af det danske ordforråd på udvandringstidspunktet.

16 Trebogstavskombinationer refererer til taler; "P" betyder kort pause i talestrømmen. 
Metakommentarer til ord fra majoritetssproget forekommer kun ved verber, adjektiver og substantiver. Dette bekræfter litteraturen der påpeger at talerne, når de kodeskifter, er mest bevidste om indholdsord (Matras 2009: 113). Tabel 6 viser at metakommentarer forekommer i markant højere grad i Argentina-datasættet end i de to øvrige datasæt.

TABEL 6. ORD FRA MAJORITETSSPROGET LEDSAGET AF METAKOMMENTARER (KUN ADJEKTIVER, SUBSTANTIVER OG VERBER)

\begin{tabular}{llll}
\hline & USA & New Denmark & Argentina \\
\hline $\begin{array}{l}\text { Ledsaget af } \\
\text { metakommentar }\end{array}$ & $50(1,9 \%)$ & $14(1,7 \%)$ & $282(18,5 \%)$ \\
Ikke ledsaget & $2.612(98,1 \%)$ & $789(98,3 \%)$ & $1.244(71,5 \%)$ \\
\hline Total & $2.662(100 \%)$ & $803(100 \%)$ & $1.526(100 \%)$ \\
\hline
\end{tabular}

Vi tager denne store forskel mellem datasættene op i diskussionen i afsnit 6 .

I forhold til ordklasser ses kulturspecifikke kodeskift som forventet kun i ordklasserne adjektiv, substantiv og verbum, og langt de fleste af dem er substantiver, hvad der også er forventeligt (Matras 2007: 32). ${ }^{17}$ De substantiviske kulturspecifikke kodeskift fordeler sig talmæssigt i de tre datasæt som vist $i$ tabel 7 .

TABEL 7. KULTURSPECIFIKKE ORD FRA MAJORITETSSPROGETS ANDEL I ORDKLASSEN SUBSTANTIV

\begin{tabular}{llll}
\hline & USA & New Denmark & Argentina \\
\hline Kulturspecifikke kodeskift & $249(14 \%)$ & $352(60 \%)$ & $379(30 \%)$ \\
Andet & $1.476(86 \%)$ & $232(40 \%)$ & $895(70 \%)$ \\
\hline Total & $1.725(100 \%)$ & $584(100 \%)$ & $1.274(100 \%)$ \\
\hline
\end{tabular}

Tabellen viser klare, signifikante forskelle mellem de tre datasæt mht.

17 I USA-datasættet ser vi fx disse tre verber der betegner aktiviteter der er karakteristiske for udvandrernes liv: hoboe 'vagabondere', homesteade 'modtage gratis landbrugsjord fra staten mod at man opdyrker det', settle 'bosætte sig'. Andre eksempler på brug af kulturspecifikke verbalstammer fra engelsk er (han) graduated (ved bojskolen) og (der var nogen til) inspect (dem kartofler). 
hvor meget de kulturspecifikke ord fra majoritetssproget fylder, ${ }^{18}$ med New Denmark som topscoreren, hvor de engelske kulturspecifikke ord fylder næsten halvdelen af alle engelske substantiver, og USA som det datasæt hvor engelske kulturspecifikke ord spiller en næsten ubetydelig rolle. Argentina-sættet indtager en mellemposition her. Der kan være flere forklaringer på dette, og det vender vi tilbage til i diskussionen efter at vi har set nærmere på distributionen af blandingsordene $i$ de tre datasæt.

\subsection{Blandingsord}

Som nævnt forekommer blandingsord $\mathrm{i}$ alle tre datasæt, men i forskellig udstrækning. Figur 1 viser en opgørelse.

FIGUR 1. DISTRIBUTION AF BLANDINGSORD PA ORDKLASSER I DE TRE DATASÆT

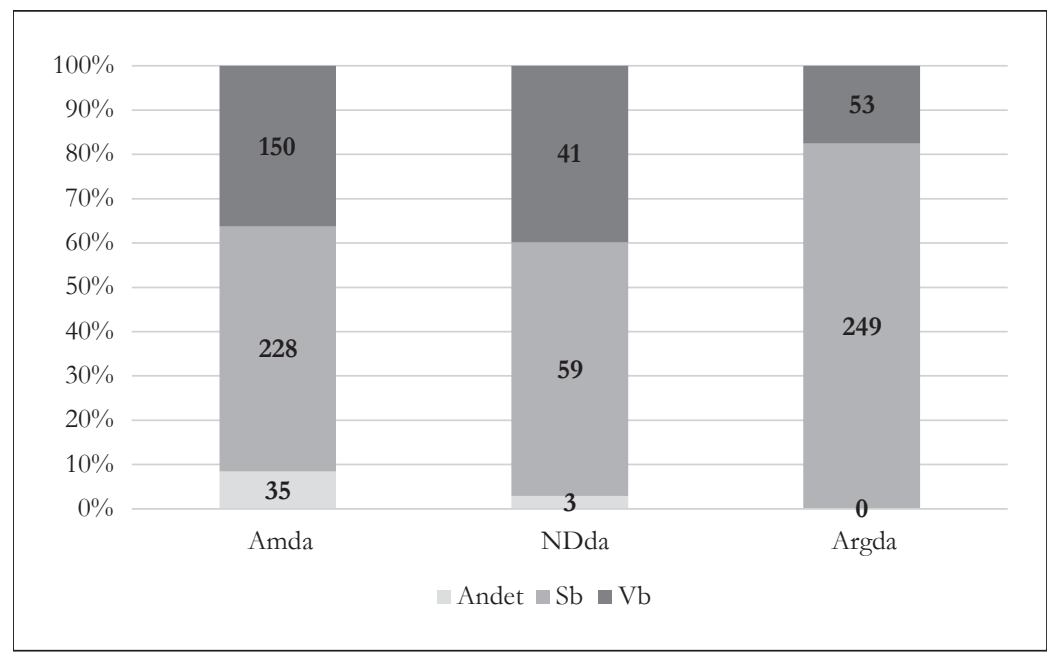

ANDET $=$ ADJEKTIV, ADVERBIUM, PRONOMEN, KONJUNKTION, PRÆPOSITION OG NUMERALER.

Som figur 1 også viser, er langt de fleste blandingsord $\mathrm{i}$ alle tre datasæt forventeligt nok enten substantiver eller verber. I Argentina-datasættet er der ingen forekomster af de øvrige ordklasser. I New Denmark-datasættet er der ét sprogligt blandet adjektiv og to sprogligt blandede ad-

18 Argentina vs. USA: $\mathrm{p}<0,001$; USA vs. New Denmark: $\mathrm{p}<0,001$. 
verbier (dailye 'daglige', mestly'for det meste' og somesteder'nogle steder'), mens adjektiver og adverbier med 35 eksempler fylder noget mere $\mathrm{i}$ USA-datasættet. ${ }^{19}$ Verbernes andel i de tre datasæt er interessant: De 53 blandings-verber i Argentina-sættet udgør ca. $18 \%$ af alle blandingsord, mens andelene er oppe på $36 \%$ og $39 \%$, i USA- og New Denmark-sættene. Denne forskel mellem Argentina- og USA-sættet er statistisk signifikant $(\mathrm{p}<0,001)$. Blandingsordene tjener altså så at sige forskellige formål i argentina- vs. nordamerikadansk.

Ser vi på sprogproduktionskonteksten som fremstillet i tabel 8, fremgår det at langt de fleste blandingsord følger efter enten danske ord eller efter tøven. Dette gælder for alle tre datasæt. Modsat for ord fra majoritetssproget har vi altså at gøre med en nogenlunde ensartet distribution på tværs af datasættene, og for især USA-sættets vedkommende er det påfaldende at blandingsord ikke i synderlig grad følger efter dels andre blandingsord (kun ét eksempel under Andre), dels ord fra majoritetssproget. Dette kan tolkes som at blandingsordene fungerer som en så naturlig del af talernes ordforråd at de i modsætning til tendensen for ord fra majoritetssproget ikke bruges som en løsning for et ordmobiliseringsproblem, og at det (derfor) ikke bemærkes af talerne i lige så høj grad.

TABEL 8. PRÆKONTEKST FOR ALLE BLANDINGSORD I DE TRE DATASÆT

\begin{tabular}{llll}
\hline & USA & New Denmark & Argentina \\
\hline Danske ord & $273(66 \%)$ & $66(64 \%)$ & $216(71,5 \%)$ \\
Ord fra majoritetssproget & $21(5 \%)$ & $6(6 \%)$ & $1(0,3 \%)$ \\
Tøven & $112(27 \%)$ & $29(28 \%)$ & $70(23,2 \%)$ \\
Andre & $7(2 \%)$ & $2(2 \%)$ & $15(5 \%)$ \\
\hline I alt & $413(100 \%)$ & $103(100 \%)$ & $302(100 \%)$ \\
\hline
\end{tabular}

TØVEN = TØVEORD, PAUSE OG SELVAFBRYDELSE. ANDRE = UFORSTÅELIGT ORD, BLANDINGSORD, PROPRIUM, UDBRUD OG SÆTNINGSINITIAL POSITION.

Denne fortolkning bliver yderligere forstærket når vi ser nærmere på hvilken type blandingsordene tilhører. For Argentina er der 48 forekomster af en verbaldannelsestype hvor en spansk stamme suffigeres

19 I USA-datasættet findes der endda eksempler på blandingsord blandt funktionsordene: someting (pron.), seksteen (num.), forcause (konj.), befor (præp.). 
med det danske trykstærke derivativ ere-, fx attend-er-e, cobr-er-e, vacacion-er-e. ${ }^{20}$ Dette ser ud til at være en produktiv måde for dansk-argentinerne at danne verber på (Heegård et al. 2018; Hartling 2019: 73-120), og verberne bruges til at betegne almene situationer og handlinger - de kan ikke regnes som kulturspecifikke. Af de tilbageværende 254 blandingsord i Argentina-datasættet er hele 194 at regne som kulturspecifikke ord (76\%). De omfatter fx mateen 'mateen', asadoen 'grillarrangementet', avenidaen 'alléen', campen 'landbrugsjorden, landbrugsejendommen', campleje 'forpagtning af landbrugsjord', eucaliptoerne 'eukalyptuserne', colectividadfest 'andelsforeningsfest', estancierosonner 'godsejersønner', yerbahost 'høst af planten yerba', yerbaprisen 'prisen på yerba'.

Også i New Denmark udgør kulturordene med $58 \%$ en stor del af blandingsordene, og langt de fleste har med landbrug, dvs. kartoffeldyrkningen, at gøre, eller de optræder i forbindelse med omtalen af talernes arbejde som kartoffeldyrkere, og de omfatter både (a) verber (med dansk fleksiv), diggede 'gravede', (blev) exportet, raisede 'dyrkede', shippede, spraye, (b) simplekssubstantiver med fleksiver, barrelen 'tønden', sakkers 'sække', trucken 'lastbilen', og (c) sammensætninger, oftest men ikke udelukkende med dansk andetled, fx, kartoffelbusiness, beeflereaturer, kartoffelharvester, pulpmollen, russetkartoffel, seedkartofler. ${ }^{21}$

I USA-sættet udgør kulturspecifikke ord ligeledes en stor del af blandingsordene (41\%), om end lidt mindre end i de to andre datasæt, og en stor del af disse har også med landbrugsarbejde at gøre, fx: acren 'arealmål', barnen 'laden', cornplanter 'maskine til majsplantning', cornorer 'majskolber', homesteade 'tage jord under bestemte betingelser', fielden, grainen 'kornet', majsharvesten, milkfabrik, milkvogne, pickede 'tog op', raisede 'dyrkede', ranchmand, tærskemachine. Men de resterende blandingsord i USA-sættet omfatter et større antal semantiske domæner end vi ser i Argentina- og New Denmark-sættene, fx ammunition factoryer, apartmentbygninger, blacksmed, carpenterarbejde, cementfinishing, choiren, clubben, creeken, crossroaden, diningrummet, governmentet, fencet, ironjernbane, jernbanecompany,

20 En ikke udtømmende liste er: alquilere 'leje', attendere 'deltage', cobrere 'dække', cocinare 'lave mad', conectere 'tilslutte', descalcifikere 'afkalke', desenere 'designe, lave et udkast', funcionere 'fungere', grabere 'optage', investigere 'investere', molestere 'forstyrre', persecutere 'forfølge', preparere 'forberede', vacacionere 'holde ferie'.

21 Se også Kühl $(2018,2019)$ mht. New Denmark-bosættelsen og 'kartoffelavlerdansk'. 
libraryen, lowlandet, membere, officen, oliecompany, oliefieldpapirsmoney, pensionet, plumtraer, railroadstationen, railroadbetjenten, real-estate-mand, riveren, saloonen, savmill, settlementet, skibsyarden, skoleteacher, skomagershop, storerne, teacheren, teams, celdreapartment.

Vi tillader os på denne baggrund forsigtigt at konkludere at blandingsord i Argentina- og New Denmark-sættene fortrinsvis dækker kulturspecifikke områder, for Argentina-sættets vedkommende dog også den semantisk almene produktive verbaldannelse med -ere-afledning til spansk verbalstamme. Denne specificering ses ikke i nær så høj grad i USA-sættet, hvor det også er ordstammer fra det almindelige, centrale ordforråd der overtages fra engelsk.

\section{OPSUMMERING OG DISKUSSION AF RESULTATERNE}

Det er et klart resultat af vores undersøgelse at USA-talerne kodeskifter mest og Argentinatalerne mindst, både hvad gælder ord fra majoritetssproget og blandingsord. Med andre ord er USA-dansk mest leksikalsk påvirket af det omgivende sprog, mens udvandrerdansk i Argentina er mindst påvirket af majoritetssproget.

Resultatet kan være en afspejling af flere forhold. Et af dem vedrører metoden: Talerne i USA (og New Denmark) har sandsynligvis været vidende om at interviewerne har kunnet tale og forstå engelsk, dvs. at kodeskift til engelsk måske nok gik imod den kommunikative norm der har været sat for interviewet (at tale dansk), men altså ikke har ledt til mis- eller ikke-forståelse. Sådan har det ikke været i Argentina, hvor nogle af interviewerne ikke har kunnet tale og forstå nok spansk, og hvor (bevidste) kodeskift til spansk derfor har været kommunikativt uhensigtsmæssige.

Et andet forhold med indflydelse på mulighederne for leksikalsk påvirkning er af sproghistorisk karakter. Engelsk og dansk har pga. den fællesgermanske herkomst og den intense nordiske indflydelse på engelsk i angelsaksisk tid mange leksikalske kognater fx see-se, well-vel, treetre osv., dvs. ord der er kendetegnet ved fælles træk i form og udtale. Det er kendt fra litteraturen at leksikalske kognater kan udløse kodeskift (Broersma og de Bot 2006). Spansk og dansk er genetisk fjernt beslægtet og har desuden historisk ikke været i så tæt kontakt at det har kunnet udløse typologisk forandring hen imod mange leksikalske kognater. 
Et makrosociolingvistisk perspektiv byder på flere forklaringer. Vi ved fra de historiske arbejder at danske bosættelser ikke har været opretholdt i synderlig lang tid i USA, og at dansk hurtigt forsvandt som samfundsetablerende sprog. Vi kan med Kühls (2015: 44) ord sige at hvis dansk har været opretholdt, har det været på trods af og ikke på grund af de socioøkonomiske omstændigheder. Engelsk har for mange af indvandrerne, og dermed også for mange af talerne i datasættet, tidligt spillet en dominerende rolle, og det er sandsynligt at sprogskiftet fra dansk til engelsk blev forudgået af en fase hvor USA-dansk har været stærkt påvirket $i$ alle henseender af engelsk, dvs. ikke kun leksikalsk, men også fx fonologisk og måske syntaktisk.

Dette forløb er i modsætning til forholdet mellem dansk og engelsk i New Denmark og dansk og spansk i bosættelserne i Argentina. Her har det danske sprog åbenlyst spillet en vigtigere rolle for udvandrernes og deres efterkommeres tilknytning til Danmark og det danske. Vi kan - lidt populært sagt, måske - se den etniske og kulturelle afgrænsning af hvad det vil sige at være indvandrer af dansk afstamning disse to steder, afspejlet sprogligt i leksikon. Det er en fremtidig opgave for forskningen i 'udvandrerdansk' om der tilsvarende kan siges at være mindre grammatisk og fonologisk påvirkning af New Denmark- og Argentinadansk end af USA-dansk.

Vi mener ligeledes at fordelingen af ordklasser både i forhold til ord fra majoritetssproget og blandingsord kan forklares typologisk og ud fra de makrosociale faktorer: Ser vi på hvilke ordklasser som ord fra majoritetssproget omfatter (tabel 3), var resultatet klart: Argentina-talerne er 'konservative' idet ord fra majoritetssproget for langt størstedelens vedkommende udgøres af (de forventelige) diskursord og substantiver, mens blandingsordene udgøres af substantiver og (få) verber. ${ }^{22}$ I USA-datasættet er de øvrige ordklasser blandt ord fra majoritetssproget langt bedre repræsenteret, og også blandt blandingsordene finder vi ikke kun substantiver og verber, men også adjektiver. Dette fund for USA ser vi - igen - som et tegn på at der er færre restriktioner mht. hvad der kan overtages fra engelsk og kombineres med dansk blandt disse talere. New Denmark udgør også her et mellemtrin. Det

22 At der ikke forekommer diskursord blandt blandingsordene, skyldes at langt de fleste diskursord er monomorfematiske. 
er derfor oplagt at se det resultat i samme makrosociolingvistiske lys som ovenfor.

Ordklasseanalysen har også et typologisk aspekt. Set over én kam er der rimelig overensstemmelse mellem litteraturens hierarkier og hvilke ordklasser vi ser repræsenteret blandt ord fra majoritetssproget: flest substantiver og diskursord, færrest adverbier, præpositioner og pronomener, som vi har slået sammen i en Anden-kategori og ikke her set nærmere på. Kun hvad angår verber, adskiller vores data (i alle tre datasæt) sig fra fx Matras' (2009) model idet der forekommer forholdsvis få verber eller verbalstammer fra kontaktsprogene i vores datasæt. Vi kan kun spekulere på hvorfor, men vores undersøgelse sætter således et (lille) spørgsmålstegn ved litteraturens foreslåede hierarkier.

Et næste argument for at de makrosociale forhold som skitseret indledningsvist og ovenfor ses afspejlet $i$ vores ordforrådsanalyse, finder vi i tabel 4 og tabel 5. Tabel 4 viste at ord fra majoritetssproget i Argentina-dataene i langt højere grad efterfølger en tøvemarkering end i USA-dataene, og at ord fra majoritetssproget i USA-sættet oftere efterfølger et andet ord fra majoritetssproget. (I begge tilfælde udgør New Denmark igen et mellemtrin.) Den sidste observation peger på at ord fra majoritetssproget i højere grad optræder i sekvenser i USA end i Argentina-sættet, altså at et leksikalsk sprogskifte så at sige udløser et mere konsekvent sprogskifte, fx så vi bought a house og murede om. Dette peger på at forekomsten af ord fra majoritetssproget i USA-dataene ikke kun er kvantitativt forskellig fra Argentina- (og New Denmark-) dataene, men også kvalitativt forskellig. Afdækningen af de nærmere leksikalske og syntaktiske (og semantiske) omstændigheder for hvordan sådanne sprogblandinger sker, er en opgave for fremtidige undersøgelser, men at de sker i højere grad blandt USA-talerne end blandt både Argentina- og New Denmark-talerne, ser vi som endnu en afspejling af sprogenes forskellige status i de tre sprogsamfund. At ord fra majoritetssproget langt oftere forudgås af en tøvemarkering (tabel 4) og/eller ledsages med en metakommentar (tabel 5) hos Argentina-talerne, både indikerer og afslører at talerne er bevidste om hvad der leksikalsk set er dansk, og hvad der ikke er. Dette ser vi som en støtte for vores fortolkning. 
Endelig så vi en stor forskel på hvor stor en andel kulturordene fylder i det leksikalske kodeskift i de tre datasæt. Vi har ovenfor påpeget med kig på New Denmark-datasættet at interviewmetoden kan have haft betydning for dette. C. Hale har i sine interviews specifikt spurgt ind til visse emner. Hverken Danske Stemmer-projektet i Argentina eller Kjær og Baumann Larsen i USA har haft samme grad af målrettethed, men også her er der i langt størstedelen af interviewene blevet spurgt ind til kulturspecifikke forhold. Det vil sige at forskellene i mængden af kulturspecifikke ord fra majoritetssprogene ikke kun kan skyldes interviewmetoden. Den ulig meget højere andel af ikke-kulturspecifikke ord fra majoritetssproget i USA-datasættet fortolker vi også som en konsekvens af en større tilbøjelighed til at bruge engelske ord, sandsynligvis også fordi interviewerne har kunnet forstå engelsk.

\section{KONKLUSION}

Kortlægningen af den leksikalske påvirkning af de udvandrerdanske varieteter i Argentina, USA og New Denmark i Canada indikerer en sammenhæng mellem mængde og type af kodeskift og hvilken form for samfund og selvforståelse de danske udvandrere har levet med i forhold til deres danske rødder: Dansk-argentinernes sprog er kun lidt præget af spanske kodeskift, med undtagelse af de mange spanske diskursord som er blevet del af varieteten, og de kulturspecifikke termer som er forankrede i dansk-argentinernes liv i Argentina. Mange af kodeskiftene til spanske substantiver eller verber er ledsaget af metakommentarer og tøven. Dette tegner et billede af et samfund der har opretholdt et dansk der fremstår leksikalsk forholdsvist upåvirket, og det afslører en høj grad af sprogkompetence der gør talerne i stand til at undgå skift til spansk i de ca. 90 minutter som interviewene typisk har varet.

USA-danskerne fremstår som dem der generelt kodeskifter mest og bruger flest ikke-kulturspecifikke engelske ord fra det centrale ordforråd. Hvor dansk-argentinerne og New Denmark-danskerne begrænser sig til indholdsord, bruger USA-danskerne engelske ord fra alle ordklasser; de bruger oftere kodeskift som består af flere engelske ord ad gangen, og de tøver mindst før de kodeskifter. Dette tegner et billede af en sprogbrug der er kendetegnet af flydende sprogskift. Årsagen til 
denne sprogbrug kan være at USA-danskerne i den tidsperiode hvor de blev optaget (mellem 1963 og 1982), ikke længere kunne tale leksikalsk upåvirket dansk i den korte tid som interviewene varede, dvs. ikke havde den fornødne sprogkompetence. En anden forklaring kan være at de ikke havde en norm der udelukkede korte skift til engelsk eller krævede en markering af skiftene ved tøven eller kommentar, dvs. en spejling af den generelle åbenhed over for det amerikanske samfund og sprog som de danske udvandrere og deres efterkommere har udvist. En tredje forklaring, der kan supplere de to førstnævnte, kan være det tætte genetisk-typologiske slægtskab mellem dansk og engelsk som ikke mindst via de leksikalske kognater skaber gode forudsætninger for skift mellem sprogene. Og sidst, men ikke mindst, har det interviewmetodologiske forhold at talerne har vidst at interviewerne har kunnet forstå engelsk, sandsynligvis også medvirket til engelske kodeskift.

New Denmark-danskerne forholder sig sprogligt mellem disse to yderpunkter, med et tæt netværk blandt de lokale dansk-canadiere, men med mange berøringspunkter med den canadiske virkelighed gennem kartoffeldyrkningen.

Vi konkluderer at forskellene i hvordan dansk er leksikalsk påvirket af det dominerende sprog i de tre sprogsamfund, dels kan relateres til interviewmetodiske forhold, dels til graden af typologisk slægtskab, men mere sandsynligt til makrosociale forskelle, såsom tæthed af netværk, sammenhold i den etniske gruppe og engagement i opretholdelsen eller videreudviklingen af dansk sprog og kultur blandt de danske udvandrere og deres efterkommere i Nord- og Sydamerika.

\section{TAK}

Vi vil gerne rette en stor tak til Carlsberg-Fondet, A. P. Møller og Hustru Chastine Mc-Kinney Møllers Fond til almene Formaal og Det humanistiske Fakultet ved Københavns Universitet for deres støtte til forskningsprojektet Danske stemmer i USA og Argentina, Københavns Universitet, 2014-2018, som alle tre forfattere har været tilknyttet. 
Jan Heegård Petersen

Institut for Nordiske Studier og Sprogvidenskab

Københavns Universitet

janhp@hum.ku.dk

Gert Foget Hansen

Institut for Nordiske Studier og Sprogvidenskab

Københavns Universitet

gertfh@hum.ku.dk

Karoline Kühl

kuehl.karoline@gmail.com

\section{LITTERATUR}

Agertoft, P. 2005. Danskheden påpampaen 1875-1950. En undersogelse af aktorer, strukturer og diskurser $i$ udviklingen af en dansk-argentinsk i provinsen Buenos Aires. Speciale. Aarhus Universitet, Aarhus.

J. Heegård Petersen, K. Kühl \& P. Bakker. (Indsendt). De nye hjem. E. Hjorth m.fl. (red.), Dansk Sproghistorie. Dansk i samspil, bind 5. København: Det Danske Sprog- og Litteraturselskab.

Bjerg, M. 1996. Entre Sofie y Tovelille. Una historia de los immigrantes daneses en la Argentina (1848-1930). Buenos Aires: Editorial Biblos. DOI: 10.3989/revindias.1996. i206.820.

Boas, H.C. \& H. Weilbacher. 2007. How universal is the pragmatic detachability scale? Evidence from Texas German discourse markers. F. Hoyt m.fl. (red.), Texas Linguistics Society 9: Morphosyntax of Underrepresented Languages, 33-58. Stanford: CSLI Publications.

Boersma, P. \& D. Weenink. 2019. Praat: doing phonetics by computer. http:/ /www.fon.hum. uva.nl/praat/ (tilgået marts 2019).

Broersma, M. \& K. de Bot. 2006. Triggered codeswitching: A corpus-based evaluation of the original triggering hypothesis and a new alternative. Bilingualism: language and cognition 9(1). 1-13. DOI: 10.1017/S1366728905002348.

Bækhøj, L. 1948. Danske i Argentina. Buenos Aires: Kriegers Forlag.

Engwald, N.R. 1938. Eldorado. København: Hasselbach.

Gardner-Chloros, P. 2009. Code-switching. Cambridge: Cambridge University Press. 
Gregersen, F., M. Maegaard \& N. Pharao. 2015. The LANCHART corpus. J. Durand, U. Gut \& G. Kristoffersen (red.), The Oxford handbook of corpus phonology, 534-545. Oxford: Oxford University Press. DOI: 10.1093/oxfordhb/9780199571932.013.007.

Grosjean, F. 2001. The bilingual's language modes. J.L. Nicol (red.), One mind, two languages. Bilingual language processing, 1-22. Malden: Blackwell.

Grøngaard Jeppesen, T. 2005. Danske i US A 1850-2000. En demografisk, social og kulturgeografisk undersogelse af de danske immigranter og deres efterkommere. Odense: Odense Bys Museer.

Grøngaard Jeppesen, T. 2010. Skandinaviske efterkommere i USA. Etniske grupper eller kerneamerikanere? Odense: Odense Bys Museer.

Hartling, A.S. 2019. Argentinadansk svanesang? En undersogelse af dansk talt af efterkommere af danske udvandrere til Argentina, med fokus pa leksikalsk semantik og acceptabilitet og på verbets stilling $i$ deklarativer med andet end subjekt på forste plads. Ph.d.-afhandling. Københavns Universitet.

Heegård Petersen, J. \& J. Albris. 2018. Argentinadansk: De dansktalende samfund i Argentina. Mål \& Male 39. 8-16.

Heegård Petersen, J. \& K. Kühl. 2017. Argentinadansk: Semantiske, syntaktiske og morfologiske forskelle til rigsdansk. NyS 52-53. 231-258. DOI: 10.7146/nys. v1i52-53.102687.

Heegård Petersen, J., K. Kühl \& A.S. Hartling. 2018. Danskargentinernes særlige grammatik. Mål \& Male 3. 18-24.

Hvidt, K. 1971. Flugten til Amerika. Eller drivkrafter i Masseudvandringen fra Danmark 1868-1914. Aarhus: Universitetsforlaget. DOI: 10.1016/0016-7185(72)900723.

Jarnum, K. 2006. Mellem Danmark og Argentina. Speciale. Københavns Universitet.

Johansen, O. 1934. Nybygger. København: Hasselbach.

Kjær, I. \& M. Baumann Larsen. 1974. "De messy ting". Om kodeskift i dansk-amerikansk. P. Andersen m.fl. (red.), Festskrift til Kristian Hald. På halufjersårsdagen 9.9.1974, 421-430. København: Akademisk Forlag.

Kühl, K. 2015. 'Det er easy at tale engelsk også’. Amerikadansk i 1960'erne og 1970'erne. NyS 47. 39-64. DOI: 10.7146/nys.v47i47.19916

Kühl, K. 2018. "Vi kan rejse og pille lige så godt som de derude”. Kartoffelavlerdansk i det østlige Canada. Mål \& male 39 (1). 17-23. 
Kühl, K. 2019. New Denmark, Canada: An exceptional case of language maintenance in a Danish immigrant settlement. Journal of Historical Sociolinguistics 5(1). 1-30. DOI: 10.1515/jhsl-2017-0042.

Kühl, K. \& J. Heegård Petersen. 2018. Argentinadansk: Argentinadanskernes særlige ordforråd. Mål \& Male (2). 10-16.

Kühl, K. m.fl. 2017. CoAmDa. Et nyt dansk talesprogskorpus. Danske talesprog 17. 131-160.

Kühl, K., J. Heegård Petersen \& G. Foget Hansen. 2019. The Corpus of American Danish: A language resource of spoken immigrant Danish in North and South America. Language Resources and Evaluation. 1-19. DOI: 10.1007/s10579-01909473-5.

Lang, E.J.N. 2005. New Denmark, New Brunswick: New approaches in the study of Danish migration to Canada, 1872-1901. Speciale. Carleton University, Ottawa. DOI: 10.22215/etd/2005-07697.

Lipski, J.M. 2005. Code-switching or borrowing? No sé so no puedo decir, you know. L. Sayahi \& M. Westmoreland (red.), Selected proceedings of the second workshop on Spanish sociolinguistics, 1-15. Sommerville: Cascadilla Proceedings Press.

Matras, Y. 1998. Utterance modifiers and universals of grammatical borrowing. Linguistics 1. 281-331. DOI: 10.1515/ling.1998.36.2.281.

Matras, Y. 2007. The borrowability of structural categories. Y. Matras \& J. Sakel (red.), Grammatical borrowing in cross-linguistic perspective, 31-73. Berlin: Mouton de Gruyter.

Matras, Y. 2009. Language contact. Cambridge: Cambridge University Press.

Muysken, P. 2000. Bilingual speech. A typology of code-mixing. Cambridge: Cambridge University Press.

Muysken, P. 2013. Two linguistic systems in contact: Grammar, phonology, and lexicon. T.K. Bhatia \& W.C. Ritchie (red.), Handbook of bilingualism and multilingualism, 193-215. London: Blackwell. DOI: 10.1002/9781118332382.ch8.

Myers-Scotton, C. 1993. Duelling languages: Grammatical structure in codeswitching. Oxford: Oxford University Press.

Myers-Scotton, C. 2002. Contact linguistics. Bilingual encounters and grammatical outcomes. Oxford: Oxford University Press.

Poplack, S. 1980. Sometimes I'll start a sentence in Spanish y termino en español. Toward a typology of code-switching. Linguistics 18. 581-618. DOI: 10.1515/ ling.1980.18.7-8.581. 
Salmons, J.C. 1990. Bilingual discourse marking: Code switching, borrowing, and convergence in some German-American dialects. Linguistics 28. 453-480. DOI: 10.1515/ling.1990.28.3.453.

Stolz, T. \& C. Stolz. 1996. Funktionswortentlehnung in Mesoamerika. Spanisch-amerindischer Sprachkontakt. Sprachtypologie und Universalienforschung 49(1). 86-123. DOI: 10.1524/stuf.1996.49.1.86.

Thomason, S.G. 2001. Language contact. An introduction. Edinburgh: Edinburgh University Press.

Worgall, L. 2011. Danske udvandrerkvinders liv i Argentina i perioden 1890-1935. En analyse med fokus på baggrunden for og optakten til udvandringen, daglige, familiare, kulturelle, emotionelle og sociale aspekter, indbefattet udfordringer og forhold kvinderne har modt. Speciale. Syddansk Universitet. 